\title{
Measured Elevation of Lightning and Aurora in the Jovian Atmosphere
}

Benn, Mathias; Jørgensen, John Leif; Denver, Troelz; Herceg, Matija; Jørgensen, Peter S.; Merayo, José M.G.; Connerney, John E. P.; Bolton, Scott J.; Levin, Steve

Publication date:

2019

Document Version

Publisher's PDF, also known as Version of record

Link back to DTU Orbit

Citation (APA):

Benn, M., Jørgensen, J. L., Denver, T., Herceg, M., Jørgensen, P. S., Merayo, J. M. G., Connerney, J. E. P., Bolton, S. J., \& Levin, S. (2019). Measured Elevation of Lightning and Aurora in the Jovian Atmosphere.

Abstract from AGU Fall Meeting 2019, San Francisco, United States.

\section{General rights}

Copyright and moral rights for the publications made accessible in the public portal are retained by the authors and/or other copyright owners and it is a condition of accessing publications that users recognise and abide by the legal requirements associated with these rights.

- Users may download and print one copy of any publication from the public portal for the purpose of private study or research.

- You may not further distribute the material or use it for any profit-making activity or commercial gain

- You may freely distribute the URL identifying the publication in the public portal 
P44A-02 - Measured Elevation of Lightning and Aurora in the Jovian Atmosphere

$\underline{\text { Link }}$

Thursday, 12 December 2019

- $16: 15-16: 30$

- Moscone South - 211-212, L2

\title{
Swirl Topics
}

- Planetary Discovery - SWIRL

\begin{abstract}
As part of the Juno MAG investigation, each magnetometer features dedicated star trackers providing accurate bias free attitude information continuously throughout the mission. These optical sensors are optimized for low-light scenarios, which enables detection of stars and objects as faint as $7-8 \mathrm{Mv}$. The Juno mission features a highly elliptical polar orbit with a period of $\sim 53$ days, with periapsis as close as $3.300 \mathrm{~km}$ above the cloud tops. In combination with the $13^{\circ}$ off pointing of the star tracker cameras from the Juno spin axis in anti-sun direction, the Jovian night side high latitude regions regularly enters the field of regard of these star trackers. This geometry facilitates imaging low light phenomenas as lightning and aurora at a large slanted angle in the upper parts of Jupiter's atmosphere. The large slant angle combined with accurate position and attitude information, permit determination of the altitude of the phenomenon studied. We present images of detected lightning events, visible wavelength aurora and the measured vertical structure, and discuss implications of these measurements for the Jovian atmosphere at the resulting altitudes.
\end{abstract}

\section{Authors}

- Mathias Benn

- DTU Space, National Space Institute, Technical University of Denmark

- John Leif Joergensen

- DTU Space, National Space Institute, Technical University of Denmark

- Troelz Denver

- DTU Space, National Space Institute, Technical University of Denmark

- Matija Herceg

- DTU Space, National Space Institute, Technical University of Denmark

- Peter S Joergensen

- DTU Space, National Space Institute, Technical University of Denmark

- Jose M.G. Merayo

- DTU Space, National Space Institute, Technical University of Denmark

- John E P Connerney

- NASA Goddard Space Flight Center

- Scott J Bolton

- Southwest Research Institute

- Steven Levin

- Jet Propulsion Laboratory 
